\title{
EFFECT OF FUNGAL METABOLITES AND AMENDMENTS ON MYCELIAL GROWTH OF RHIZOCTONIA SOLANI
}

\author{
Vibha*
}

Department of Plant Pathology, Rajendra Agriculture University, Pusa (Samastipur), Bihar, India

Received: June 18, 2009

Accepted: December 4, 2009

\begin{abstract}
A shift towards organic farming suggests amalgamation of organic resources against soil borne plant pathogens. The influence of metabolites of most ubiquitous Aspergillus spp., organic amendment extracts and their combined effect with Trichoderma virens were evaluated in vitro against Rhizoctonia solani. The minimum $(36.1 \mathrm{~mm})$ growth was attained by $R$. solani in co-culture with A. niger. The maximum $(42.3 \mathrm{~mm})$ inhibition of mycelial growth of the test organism was observed with culture filtrate of A. ochraceous followed by A. niger, A. fumigatus, A. flavus and A. terreus. Among organic amendment extractants, castor cake exhibited an additive effect on the growth of $T$. virens, however, the maximum $(41.8 \mathrm{~mm})$ suppressive effect on $R$. solani was observed with vermicompost. With the advance in time, the effect of organic amendment extracts increased markedly. Inhibition potential of culture filtrate mixturte of $A$. niger $+T$. virens and A. ochraceous $+T$. virens against $R$. solani was significantly higher in comparison to the other combinations.
\end{abstract}

Key words: Aspergillus spp., culture filtrate, organic amendment extracts, Rhizoctonia solani, Trichoderma virens

\section{INTRODUCTION}

Rhizoctonia solani Kühn, the causal agent of rice (Oryza sativa) sheath blight, is one of the notorious diseases of rice. Crop losses usually vary from negligible to 50 per cent depending on cultivars, cultural conditions, extent of severity of disease, crop growth stage and environmental conditions (Kannaiyan and Prasad 1976; Laha and Venkatraman 2001). Looking at the seriousness of hazards due to chemicals, eco-friendly approaches should have been followed to control the disease. Need of biological control was recognized since few decades because control of soil borne diseases through other control strategies has not resulted in promising means of management against these pathogens. Disease suppression is an inherent property of soil which is caused by the dominance and pre-dominance of Aspergillus spp., Trichoderma spp. and Fusarium spp. inhabiting soil, which was reported by various workers (Singh 2001; Valenzuela et al. 2001). Trichoderma, Gliocladium, Aspergillus etc. have been found effective in controlling sheath blight and extensively explored for control of soil borne plant pathogens (Khan and Sinha 2005).

At the same time the use of organic amendments as food base for biological control agents and their use well ahead of planting can be very effective in controlling many soil borne pathogens including $R$. solani has been already recognized (Hoitink and Boehm 1999). Compost prepared from lignolytic substances are predominantly colonized by Trichoderma spp. (Kuter et al. 1983) while Aspergillus and Penicillium isolates prefer waste of low cellulosic substance and high in sugar (Gorodecki and Hadar 1990). Parasitism is critical to biological control of $R$. solani in suppressive compost amended substrate (Nelson et al. 1983; Gorodecki and Hadar 1990) because R. solani has much narrower spectrum of biocontrol and this mycoflora does not consistently colonized composts (Grebus et al. 1994). The present investigation was undertaken to find out:

1. Probable way (individual presence or metabolite) of disease suppression by Aspergillus spp. predominantly found in to the soil after harvest of rice.

2. Suitable organic amendment supportive and suppressive to T. virens and $R$. solani, respectively.

3. Joint effect on parasitism of T. virens with metabolites of Aspergillus spp. and organic amendment extracts against test pathogens.

\section{MATERIALS AND METHODS}

\section{Fungal culture}

In the present investigation five Aspergillus spp. were evaluated against $R$. solani. These species were obtained from calciorthent (free $\mathrm{CaCo}_{3} 33$ per cent) soil of rice field under conservation tillage operation. A. niger (An), A. fumigatus (Afi), A. flavus (Af), A. ochraceous (Ao) and A. terreus (At) were isolated using dilution plate technique (Warcup 1960). T. virens was isolated from rhizospheric soil of guava plant (Psidium guajava L.).

$R$. solani was obtained from naturally infected rice plant under conservation tillage practice. All fungal cultures were maintained on potato dextrose agar (PDA) medium for further use. 


\section{Antagonism in dual culture}

Dual culture method of Morton and Stroube (1955) on PDA was used for evaluating the antagonistic activities of Aspergillus spp. $20 \mathrm{ml}$ sterilized melted PDA was poured in sterilized Petri plates, allowed to solidify and a $10 \mathrm{~mm}$ mycelial discs (from 7 days old culture) of Aspergillus spp. were placed against $R$. solani in each PDA plate. The distance between the two discs were maintained approximately at $6 \mathrm{~cm}$ away from each other. Four replications of each treatment were incubated at $25 \pm 1^{\circ} \mathrm{C}$. Observations were recorded after 48 and 96 hours.

Effect of culture filtrate of Aspergillus spp. on R. solani

Effect of culture filtrate of Aspergillus spp. on growth of $R$. solani was studied by slightly modified to method of Dennis and Webster (1971). Filtrate of antagonist(s) culture in PDA broth for 10 days was collected after passing it twice through Whatman filter paper No. 1. These filtrates were used to amend Petri plates containing PDA at 5 per cent concentration and incubated at $25 \pm 1^{\circ} \mathrm{C}$. An unamended Petri plate served as check (control). The observations of radial growth of test pathogen were recorded after 48 and 96 hours.

Effect of organic amendment on $R$. solani and $T$. virens

Four oil free cakes viz., neem (Azadirachta indica) cake (NC), karanj (Pongamia pinnata) cake (KC), mustard (Brassica juncea) cake (MC) and castor (Ricinus communis) cake (CC) and two composts of Farm yard manure (FYM) and vermicompost (VC) as organic amendment along with mixture of all cakes and compost extract were used individually to study their effect on mycelial growth of $R$. solani and T. virens. $10 \mathrm{~g}$ powder of different cakes and composts were mixed thoroughly in solution containing ethanol and water in $3: 2(\mathrm{v} / \mathrm{v})$. The mixture was kept on shaker at $24^{\circ} \mathrm{C}$ for 24 hours at $150 \mathrm{rpm}$. The solution was filtered through muslin cloth and refiltered through Whatman filter paper No. 1. The obtained filtrate was concentrated through evaporating the ethanol on hot water bath for $10 \mathrm{~min}$. This concentrated solution of each cake, compost and their mixture were used at the rate of 5 per cent in potato dextrose agar in each Petri plates. A centrally placed $10 \mathrm{~mm}^{2}$ size of mycelial discs (from
7 days old culture) of $T$. virens and $R$. solani were placed individually on amended Petri plates in triplicate at $25 \pm 1^{\circ} \mathrm{C}$ along with control. The observations of mycelial growth of both fungi were recorded after time intervals of 48 and 96 hours.

\section{Integrated effect of extractant of organic amendment} and culture filtrate of Aspergillus spp. and T. virens

The extracts of two organic amendments (KC and CC), culture filtrate of five Aspergillus spp. and T. virens were used to find best combination against $R$. solani. Apart from extracts of two cakes, combination of culture filtrate of T. virens was made with culture filtrate of Aspergillus spp. and castor cake extracts in $1: 1(\mathrm{v} / \mathrm{v})$. Mycelial disc of $10 \mathrm{~mm}$ size (from 7 days old culture) of T. virens and $R$. solani was placed at approximately $6 \mathrm{~cm}$ away from each other in $9 \mathrm{~cm}$ Petri plate containing different combinations in triplicate along with control. These Petri plates were incubated at $25 \pm 1^{\circ} \mathrm{C}$ and observations of mycelial growth were made after 96 hours.

The entire experiment was conducted under Completely Randomized Design (CRD) to analyse statistically with three replications under laboratory conditions at Rajendra Agriculture University, Pusa (Samastipur), Bihar, India during 2008-2009.

\section{RESULTS}

Antagonistic effect of Aspergillus spp. against R. solani

All five Aspergillus spp. exhibited growth suppressing ability against $R$. solani (Table 1$)$. A. niger was found the most effective antagonist against of $R$. solani in suppressing the growth and proved statistically superior (39.8 mm) as compared to the Aspergillus spp. tested. The minimum $(36.1 \mathrm{~mm})$ growth was attained by $R$. solani in co-culture with $A$. niger followed by A. flavus $(38.0 \mathrm{~mm})$, A. fumigatus $(39.5 \mathrm{~mm}), A$. ochraceous $(42.8 \mathrm{~mm})$ and A. terreus $(49.5 \mathrm{~mm})$. This result indicates that $A$. niger is the best biocontrol agent against $R$. solani, however, $A$. fumigatus and $A$. flavus are identical but significantly higher antagonistic potentials to other Aspergillus spp.

The effect of culture filtrate of fungal antagonist on the growth of $R$. solani was found statistically significant

Table 1. Antagonistic effect of Aspergillus spp on R. solani through dual culture and poison food method

\begin{tabular}{|c|c|c|c|c|c|}
\hline \multirow{2}{*}{ Aspergillus spp. } & \multicolumn{2}{|c|}{ Time [hours] ${ }^{*}$} & \multicolumn{2}{|c|}{ Growth of $R$. solani $[\mathrm{mm}]^{* *}$} & \multirow{2}{*}{ Mean } \\
\hline & 48 & 96 & dual & metabolite & \\
\hline A. niger & 41.1 & 38.5 & 36.1 & 43.5 & 39.8 \\
\hline A. terreus & 40.1 & 62.8 & 49.5 & 53.5 & 51.5 \\
\hline A. ochraceous & 34.6 & 50.5 & 42.8 & 42.3 & 42.5 \\
\hline A. fumigatus & 41.1 & 48.7 & 39.5 & 50.4 & 44.9 \\
\hline A. flavus & 39.0 & 51.5 & 38.0 & 52.5 & 45.2 \\
\hline Control & 49.1 & 58.5 & 53.8 & 53.8 & 53.8 \\
\hline Mean & 40.9 & 51.7 & 43.3 & 49.3 & \\
\hline $\mathrm{CD}(\mathrm{p}=0.05)$ & \multicolumn{2}{|c|}{0.62} & \multicolumn{2}{|c|}{0.62} & 0.44 \\
\hline
\end{tabular}

* interaction effect of Aspergillus spp. x time

**interaction effect of Aspergillus spp. x methods

$\mathrm{CD}$ - Critical difference 
except of A. terreus and control. Maximum (42.3 mm) inhibition of mycelial growth of the test organism was observed with culture filtrate of $A$. ochraceous. Culture filtrate of A. niger, A. fumigatus, A. flavus and A. terreus inhibited radial growth of $R$. solani by $43.5,50.4,52.5$ and $53.5 \mathrm{~mm}$, respectively. Interaction between Aspergillus spp. and time was significant. Antagonistic effect of $A$. ochraceous was more conspicuous with time after 48 hours, whereas that of A. niger was observed after 96 hours. Dual culture per se

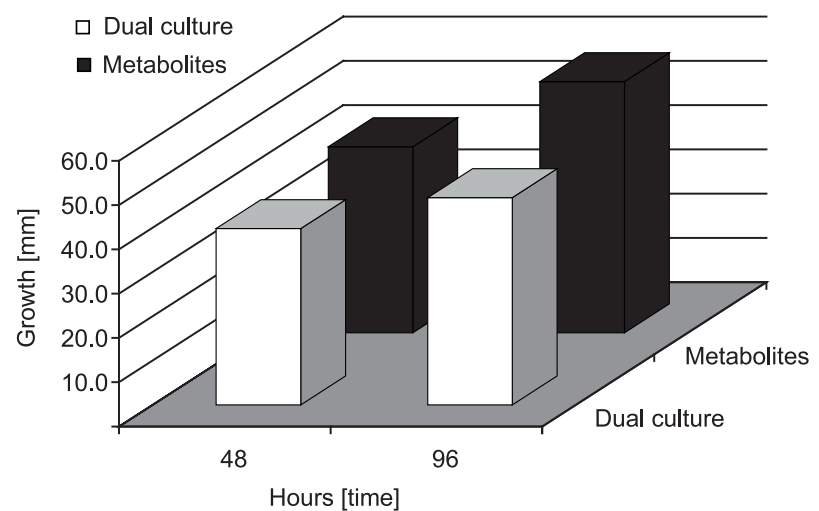

Fig. 1. Interaction effect on growth of $R$. solani with time resulted in remarkably higher suppression as compared to metabolites (Fig. 1).

\section{Effect of organic amendment extractant on T. virens and} R. solani

All the seven amendments had significantly supportive effect on T. virens whereas detrimental effect on $R$. solani. The highest $(20.2 \mathrm{~mm})$ growth inhibitory effect was observed with mixed cake irrespective of the test organisms at different time intervals (Table 2). After 48 hours, maximum $(36.7 \mathrm{~mm})$ growth was supported by karanj cake followed by vermicompost $(32.6 \mathrm{~mm})$ and castor cake $(32.4 \mathrm{~mm})$, the later two had statistically identical effect. After 96 hours, castor cake was the most $(79.2 \mathrm{~mm})$ supporting amendment while the least effect $(53.3 \mathrm{~mm})$ had mustard cake. With the advance in time, effect of organic amendment increased markedly (Fig. 2). The highest $(61.1 \mathrm{~mm})$ growth of $T$. virens was supported by castor cake. FYM $(47.8 \mathrm{~mm})$ and vermicompost $(47.4 \mathrm{~mm})$ had identical effect on T. virens. Growth suppressive effect was observed for mustard cake in case of T. virens. Mixed cake was found statistically superior to other amendments in inhibiting the growth of $R$. solani being followed by vermicompost.

Table 2. Effect of organic amendment extract on T. virens and R. solani

\begin{tabular}{|l|c|c|c|c|c|}
\hline \multirow{2}{*}{\begin{tabular}{c}
\multirow{2}{*}{$\begin{array}{c}\text { Organic } \\
\text { emendment } \\
\text { extracts }\end{array}$} \\
\cline { 2 - 5 }
\end{tabular}} & 48 & 96 & T. virens & R. solani & \multirow{2}{*}{ Mean } \\
\hline Neem cake & 29.6 & 67.7 & 52.4 & 45.0 & 48.7 \\
\hline Karanj cake & 36.7 & 62.0 & 54.1 & 44.5 & 49.3 \\
\hline Mustard cake & 27.2 & 53.3 & 33.5 & 47.0 & 40.2 \\
\hline FYM & 29.0 & 66.5 & 47.8 & 47.5 & 47.7 \\
\hline Vermicompost & 32.6 & 56.5 & 47.4 & 41.8 & 44.6 \\
\hline Mixed cake & 14.1 & 26.4 & 20.6 & 19.9 & 20.2 \\
\hline Castor cake & 32.4 & 79.2 & 61.1 & 50.5 & 55.8 \\
\hline Control & 42.1 & 57.1 & 44.8 & 54.4 & 49.6 \\
\hline Mean & 30.5 & 58.6 & 45.2 & 43.8 & \\
\hline CD $(p=0.05)$ & \multicolumn{2}{|c|}{1.21} & & \\
\hline
\end{tabular}

*intercation effect of organic amendment extractant $x$ time

** intercation effect of organic amendment extractant $x$ organism

CD - Critical difference; FYM - Farma yard manure

Table 3. Effect of extract of cakes and metabolites of fungi on growth of T. virens and R. solani in dual culture

\begin{tabular}{|l|c|c|c|}
\hline \multicolumn{1}{|c|}{ Treatments } & T. virens & R. solani & Mean \\
\hline Castor cake & 62.0 & 26.6 & 44.3 \\
\hline Karanj cake & 61.6 & 26.6 & 44.1 \\
\hline An $+\mathrm{Tv}+\mathrm{CC}$ & 58.5 & 30.0 & 44.2 \\
\hline An $+\mathrm{Tv}$ & 61.1 & 23.1 & 42.1 \\
\hline Afi $+\mathrm{Tv}$ & 52.8 & 36.6 & 44.7 \\
\hline Ao $+\mathrm{Tv}$ & 53.8 & 23.5 & 38.6 \\
\hline Af $+\mathrm{Tv}$ & 61.3 & 26.1 & 43.7 \\
\hline Control & 54.5 & 49.1 & 51.8 \\
\hline Mean & 58.2 & 30.2 & 1.64 \\
\hline CD $(p=0.05)$ & \multicolumn{2}{|c|}{2.33} & \\
\hline
\end{tabular}

An - A. niger; Tv - T. virens; CC - castor cake; Afi - A. fumigatus; Af - A. flavus; Ao - A. ochraceous; CD - Critical difference 


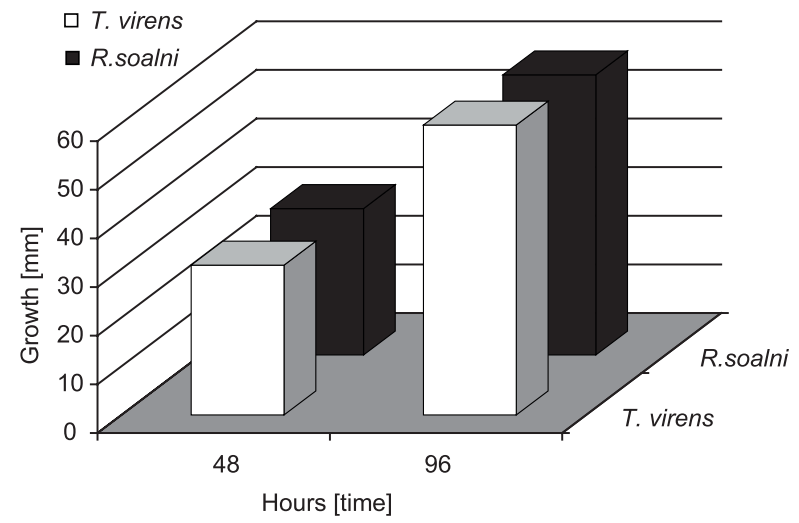

Fig. 2. Interaction effect on organisms with time

Combined effect of culture filtrate and organic amendment extractant on $T$. virens and $R$. solani in dual culture

Significant effect on growth of both species (beneficial and pathogenic) was observed in dual culture (Table 3). Organic amendment extractant, organic amendment extracts and metabolites (A. niger and T. virens), metabolites of Aspergillus spp. and T. virens had marked stimulatory and suppressive effect on growth of co-culture of T. virens and R. solani. Castor cake showed the higher $(62.0 \mathrm{~mm})$ stimulatory effect on $T$. virens followed by karanj cake $(61.6 \mathrm{~mm})$ and metabolites of A. flavus and T. virens $(61.3 \mathrm{~mm})$. All possible combinations in present study had inhibitory effect on growth of $R$. solani. However, inhibition potential of metabolites of $A$. niger $+T$. virens and $A$. ochraceous $+T$. virens was found statistically higher compared to other treatments. Castor cake, karanj cake and metabolites of $A$. flavus $+T$. virens had similar suppressive effect on $R$. solani.

\section{DISCUSSION}

Parasitism is the first step in biological control of pathogen where hyphal interaction between the pathogenic fungi and beneficial organism takes place. Under dual culture myco-parasitism was tested, the highest growth suppressing ability was observed with $A$. niger against $R$. solani. This may be attributed to fast growth and sporulation coupled with metabolites secreted from the sporulating fungi which results in lysis of the host cell. Sen et al. (1993) reported A. niger, an effective biological control agent against $R$. solani by way of antibiosis, overgrowth and hyperparasitism.

Aspergillus spp. studied under the present investigation is well known for secreting toxigenic compound around its surrounding. The highest growth inhibition of $R$. solani was observed with $A$. ochraceous which might be due to the presence of ochratoxin in the culture filtrate. Literature is scanty to support this finding, however, there is evidence that suggests the ochratoxin being injurious to human health but ochratoxin B derivative is non-toxigenic against human being (Dube 1999) which might get triggered on after interacting with enzymes of actively growing enzymatically active $R$. solani.

The best supporting organic amendment extract for the growth of $T$. virens were that of castor and karanj cakes at different time intervals. A probable reason behind this finding might be due to the presence of organic nitrogen, carbon in complex form, humic acid and absence of toxic compounds in these substrates. Trichoderma spp. predominantly colonize the substrate prepared from lignocellulosic material like tree bark (Kuter et al. 1983). Mixed cake extracts resulted in higher suppression of growth of both fungi due to higher accumulation of nitrogen in amide and amino acid form. Lazarovits (2001) reported that organic amendments of high nitrogen content have a potential to suppress both the soil borne pathogen (and beneficial organisms) through the toxic effect of ammonia and nitrous acid. Vermicompost was found next to mixed cake that supported a poor growth of $R$. solani. Detrimental effect of vermicompost on $R$. solani may be ascribed to low nitrogen content, presence of heavy metal ions and low cellulose content. The pathogenic fungi $R$. solani is highly competitive as a saprophyte. It can utilize cellulose and colonize fresh organic material, but does not colonize mature, low cellulose compost (Hoitink et al. 1996).

Apart from castor and karanj cakes growth supportive effect on $T$. virens was also observed with mixture of metabolites of $A$. niger + T. virens while the same combination had opposite effect on $R$. solani. The maximum inhibitory effect against $R$. solani was found with mixed metabolites of $A$. niger $+T$. virens and $A$. ochraceous $+T$. virens. The probable reason behind this finding might be attributed to the production of antibiotics, humic acid like substances, maturity index of the amendment along with the hyphal interaction between T. virens and R. solani in dual culture on amended substrate. Apart from secreting aflatoxin, A. niger also produces humic acid substance. The constituents of humic acid are highly stable organic matter that does not break down further. Hence, nutrients for growth become a limiting factor against the test pathogen. In addition to competition, parasitism was also reported as a mechanism for suppressing Rhizoctonia spp. in growing media (Hoitink and Boehm 1999). During hyphal interaction it was observed that $T$. virens is interacting with $R$. solani. Initially, T. virens was running along the host hyphae but later $R$. solani exhibited disintegrated appearance which might be due to production of lytic enzyme by T. virens. Several traits that may contribute to antagonistic interaction of $T$. virens with disease causing fungi involve production of a peptide metabolite like gliotoxin which was reported by Wilhite et al. (2001).

\section{CONCLUSION}

The current study suggests that $A$. niger was the most effective antagonist against $R$. solani, culture filtrate of $A$. ochraceous had maximum inhibitory effect on growth of the test pathogen, mixed cake extract had detrimental effect on both beneficial and pathogenic fungi, karanj cake supported the maximum growth of $T$. virens while combination of $A$. niger $+T$. virens was most aggressive towards suppressing the growth of the test pathogen. Following the pattern of enhancement of soil native mycoflora, incorporation of organic amendment and bio-control agent is suggestive as achievement of sustainable disease management against sclerotia forming pathogen of rice. 


\section{REFERENCES}

Dennis C., Webster J. 1971. Antagonistic properties of species group of Trichoderma III. Hyphal interaction. Trans. Br. Mycol. Soc. 57: 363-369.

Dube H.C. 1999. Mycotoxin and mycotoxicoses. In: "An Introduction to Fungi". Vikas Publishing House Pvt. Ltd., New Delhi, India, 608 pp.

Gorodecki B., Hadar Y. 1990. Suppression of Rhizoctonia solani and Sclerotium rolfsi in container media containing composted separated cattle manure and composted grape marc. Crop Protect. 9: 271-274.

Grebus N.E., Watson M.E, Hoitink H.A.J. 1994. Biological, chemical and physical properties of composted yard trimmings as indicators of maturity and plant disease suppression. Compost Sci. Util. 2 (1): 57-71.

Hoitink H.A.J., Boehm M.J. 1999. Biocontrol within the context of soil microbial communities: A substrate dependent phenomenon. Ann. Rev. Phytopathol. 37: 427-446.

Hoitink H.A.J., Stone A.G., Grebus M.E. 1996. Suppression of plant diseases by composts. p. 373-381. In: "The Science of Composting" (M. De Bertoldi, P. Sequi, B. Lemmes, T. Papi, eds.). Blackie Academic \& Professional, Glasgow. Vol. 1, 1055 pp.

Kannaiyan S., Prasad U.N. 1976. Efficacy of certain fungicides on control of sheath blight. Int. Rice Res. Newsletter 1, p. 19.

Khan A.A., Sinha A.P. 2005. Influence of different factors on the activity of fungal bioagents to manage sheath blight of rice in nursery. Ind. Phytopathol. 58: 289-293.

Kuter G.A., Nelson E.B., Hoitink H.A.J., Madden L.V. 1983. Fungal populations in container media amended with composted hardwood bark suppressive and conducive to Rhizoctonia damping-off. Phytopathology 73: 1450-1456.

Laha G.S., Venkatraman S. 2001. Sheath blight management in rice with biocontrol agents. Ind. Phytopathol. 54: 461-464.

Lazarovits G. 2001. Management of soilborne plant pathogens with organic soil amendments: A disease control startegy salvaged from the past. Can. J. Plant Pathol. 23: 1-7.

Morton D.J., Stroube W.H. 1955. Anatagonistic and stimulating effects of soil micro-organisms upon Sclerotium. Phytopathology 45: 417-420.

Nelson E.B., Kuter G.A., Hoitink H.A.J. 1983. Effect of fungal antagonist and compost age on suppression of Rhizoctonia damping-off in container media amended with composted with hardwood bark. Phytopathology 73: 1457-1462.

Sen B., Sharma J., Asalmol M.N., Chattopadhyay C., Patibanda A.K. 1993. Aspergillus niger - A potential biocontrol agent for soil borne pathogens. Ind. Phytopathol. 46 (3): 275-278.

Singh A. 2001. Studies on Fungal Decomposition of Sunhemp (Crotolaria juncea L.) in Soil. Ph.D. Thesis, Banaras Hindu University, Varanasi, India, 83 pp.

Valenzuela E., Leiva S., Godoy R. 2001. Seasonal variation and enzymatic potential of microfungi associated with the decomposition of Northofagus pumilio leaf litter. Rev. Chil. Hist. Nat. 74 (4): 737-749.

Warcup J.H. 1960. Method for isolation and estimation of activity of fungi in soil. p. 3-21. In: "Ecology of Soil Fungi" (D. Parkinson, J.S. Waid, eds.). The University Press, Liverpool.

Wilhite S.E., Lumsden R.D., Straney D.C. 2001. Peptide synthatase gene in T. virens. Appl. Environ. Microbiol. 67 (11): 5055-5062.

\section{POLISH SUMMARY}

\section{DZIAŁANIE METABOLITÓW GRZYBOWYCH I WYCIĄGÓW ORGANICZNYCH NA WZROST GRZYBNI RHIZOCTONIA SOLANI}

W produkcji ekologicznej sugeruje się połączenie organicznych źródeł przeciwko patogenom odglebowym. Oceniono wpływ metabolitów powszechnie występujących gatunków Aspergillus, organicznych wyciągów i ich łączne działanie z Trichoderma, przeciwko Rhizoctonia solani. Najmniejszy wzrost $(36,1 \mathrm{~mm})$ R. solani odnotowano w podwójnej kulturze z A. niger. Maksymalną inhibicję $(42,3 \mathrm{~mm})$ wzrostu grzybni testowego mikroorganizmu zaobserwowano w przypadku filtratu kultury z A. ochraceous, a następnie z A. niger, A. fumigatus, A. flavus i $A$. terreus. Spośród wyciągów, te z rącznika wykazywały stymulujące działanie na wzrost $T$. virens, a maksymalne $(41,8 \mathrm{~mm})$ supresyjne działanie na $R$. solani obserwowano $\mathrm{w}$ przypadku wermikompostu. $\mathrm{Z}$ czasem, działanie wyciągów z organicznych dodatków znacznie wzrastało. Potencjał inhibicyjny mieszaniny filtratu kultury $A$. niger $+T$. virens i $A$. ochraceous $+T$. virens przeciwko $R$. solani był istotnie wyższy w porównaniu z innymi kombinacjami. 